\title{
Pengaruh employee stock option plan (ESOP) terhadap earnings management (studi pada perusahaan yang listed di bursa efek indonesia periode 2015 - 2017)
}

\author{
Betty Wulansari, Satia Nur Maharani* \\ Universitas Negeri Malang, Jl. Semarang No. 5 Malang, Jawa Timur, Indonesia \\ *Penulis korespondensi, Surel: satia.nur.fe@um.ac.id
}

Paper received: 1-4-2021; revised: 22-4-2021; accepted: 29-4-2021

\begin{abstract}
This Study aimed to determine the effect of ESOP on Earnings Management. The populations of this study were all companies listed on the Indonesia Stock Exchange for the period 2015-2017. The sample was determined by purposive sampling technique and obtained 30 company's annual reports as the sample. The data collection method used secondary data documentation techniques that was obtained from the website www.idx.co.id. Data analysis was performed using panel data regression analysis. The results showed that the ESOP had no effect on Earnings Management.
\end{abstract}

Keywords: employee stock option plan; earnings management; go public company

\begin{abstract}
Abstrak
Penelitian ini bertujuan untuk mengetahui pengaruh ESOP terhadap Earnings Management. Populasi penelitian ini seluruh perusahaan yang terdaftar di Bursa Efek Indonesia periode 2015-2017. Sampel ditentukan dengan teknik purposive sampling dan diperoleh sampel 30 laporan tahunan perusahaan. Teknik pengumpulan data menggunakan teknik dokumentasi data sekunder yang diperoleh dari website www.idx.co.id. Analisis data menggunakan analisis regresi data panel. Hasil penelitian menunjukkan ESOP tidak berpengaruh terhadap Earnings Management.
\end{abstract}

Kata kunci: employee stock option plan; earnings management; perusahaan go public

\section{Pendahuluan}

Pada dasarnya, dalam hubungan keagenan yang dijelaskan melalui teori agensi (agency theory) menjelaskan bahwa manajer dikontrak oleh pemegang saham untuk memenuhi kepentingannya. Untuk itu, manajer diberikan kekuasaan dalam mengatur perusahaan dengan tujuan membuat keputusan yang terbaik. Kondisi ini dapat menimbulkan asimetri informasi, dimana manajer akan lebih mengetahui informasi internal dan prospek perusahaan di masa depan dibandingkan dengan pemegang saham dan para pemangku kepentingan lainnya (Trisnawati et al., 2015). Adanya asimetri informasi dapat memberi kesempatan

kepada manajer untuk melakukan tindakan yang memaksimalkan keuntungan pribadinya dengan melakukan tindakan manajemen laba. Richardson (1998) menyatakan bahwa terdapat hubungan sistematis antara asimetri informasi dengan manajemen laba.

Menurut Scott (2012) manajemen laba adalah pemilihan kebijakan akuntansi oleh manajer atau tindakan yang dapat mempengaruhi laba. Manajemen laba akan membuat laba tidak sesuai dengan keadaan yang sebenarnya karena laba yang ditampilkan mengikuti keinginan manajer (Syariati et al., 2017). Tujuan manajer melakukan tindakan yaitu untuk memberikan gambaran yang positif terkait kinerja perusahaan karena laporan keuangan 
digunakan sebagai cerminan kemampuan dan efektivitas manajer dalam mengelola perusahaan (Harris et al., 2019).

Kasus terkait dengan tindakan manajemen laba masih banyak dilakukan sampai saat ini tidak terkecuali di Indonesia seperti yang dialami PT Garuda Indonesia. Terungkapnya kasus PT Garuda Indonesia saat komisaris Garuda Indonesia, yaitu Chairul Tanjung dan Dony Oskaria meragukan lonjakan laba bersih sebesar USD 809,85 ribu yang diperoleh tahun 2018. Setelah dilakukan penyelidikan, ternyata peningkatan laba tersebut berasal dari pengakuan pendapatan yang semestinya tidak diakui pada tahun berjalan, melainkan harus diakui sebagai piutang, yaitu sebesar USD 239 juta (Hartomo, 2019). Lebih lanjut, Iskan (2019) mengungkapkan bahwa yang melatarbelakangi perusahaan publik melakukan tindakan manipulasi laporan keuangan antara lain untuk menipu pasar supaya harga saham naik, politik, dan bagi manajer adalah mengejar bonus. Garuda Indonesia adalah perusahaan publik milik negara yang memiliki sistem bonus tantiem untuk manajemennya, dimana bonus diberikan ketika perusahaan memperoleh laba (Iskan, 2019).

Adanya kasus di atas, dapat menjadi pembelajaran kepada perusahaan dan pemegang saham, bahwa saat memberikan kompensasi kepada karyawan dan manajer berupa bonus harus berhati-hati. Ross (1973) dalam Mitnick (2013) mengungkapkan bahwa salah satu permasalahan berat yang dihadapi perusahaan adalah pemilihan sistem kompensasi yang menghasilkan perilaku manajer konsisten dengan kepentingan pemegang saham. Jensen dan Meckling (1976) mengemukakan bahwa sistem kompensasi berupa insentif ekuitas dapat memotivasi manajer mengambil tindakan yang konsisten dengan kepentingan pemegang saham, dengan demikian mengurangi masalah keagenan termasuk manajemen laba.

Di Indonesia pemberian insentif ekuitas dinamakan dengan Program Opsi Saham Karyawan/Employee Stock Option Plan (POSK/ESOP). ESOP adalah pemberian hak kontraktual atau opsi kepada karyawan untuk membeli saham perusahaan sepanjang periode waktu tertentu dan membayar dengan harga yang telah ditetapkan saat tanggal pemberian (Bapepam, 2002). Keberadaan ESOP memberikan keuntungan kepada perusahaan karena dapat menghubungkan kemakmuran karyawan dengan nilai perusahaan yang berdampak terhadap kekayaan pemegang saham, sehingga hal ini dapat mengatasi masalah keagenan (Oyer \& Schaefer, 2005).

Penelitian sebelumnya yang dilakukan oleh Essid (2012) dan Hassen (2014) mengemukakan bahwa adanya insentif ekuitas dapat memperkecil tindakan manajemen laba. Essid (2012) menemukan bahwa opsi saham eksekutif (ESO) menurunkan manajemen laba karena opsi saham dapat menjadi mekanisme kontrol yang efisien. Penelitian ini didukung oleh Hassen (2014) yang menjelaskan bahwa total kompensasi eksekutif berpengaruh negatif terhadap nilai manajemen laba. Hal ini dikarenakan eksekutif yang memiliki kompensasi tinggi akan termotivasi untuk mempertahankan pekerjaan di perusahaan dan dengan demikian menghindari risiko pergantian.

Berbeda dengan penelitian-penelitian di atas, beberapa penelitian terbaru meragukan efektivitas dari insentif ekuitas (Bebchuk \& Fried, 2003; Chen et al., 2015; Shan \& An, 2018) karena dalam praktiknya dapat menimbulkan serangkaian konflik antara manajer dengan pemegang saham, sehingga mendorong eksekutif terlibat dalam tindakan manajemen untuk mendapatkan keuntungan pribadi. Lebih lanjut, Goldman \& Slezak (2006) juga menyatakan bahwa insentif berbasis ekuitas atau opsi saham menggambarkan pedang bermata dua. Disatu 
sisi memang dapat memotivasi produktivitas manajer, sehingga meningkatkan kinerjanya. Akan tetapi, pada saat yang sama juga dapat mendorong manajer untuk menggambarkan kinerja yang salah untuk memenuhi kepentingan pribadinya dengan melakukan tindakan manajemen laba.

Tindakan manajemen laba yang dilakukan berupa manipulasi laba dengan menurunkan jumlah laba sebelum penerapan ESOP (Liu et al., 2014; McAnally et al., 2008; Wu et al., 2012) dan menaikkan jumlah laba setelah penerapan ESOP (Asyik, 2006; Syariati et al., 2017). Tindakan manipulasi laba tersebut dilakukan untuk mempengaruhi harga saham supaya sebelum ESOP diterapkan harga saham menjadi turun, sehingga opsi saham dapat dibeli dengan harga yang murah. Kemudian, setelah penerapan ESOP harga saham menjadi meningkat tujuannya untuk memaksimalkan nilai opsi saham. Semakin tinggi laba yang dihasilkan perusahaan memiliki pengaruh positif terhadap harga saham (Shabani et al., 2014). Ketika harga saham naik, pemberian insentif berupa opsi saham akan menjadi lebih berharga bagi manajer karena hal tersebut memengaruhi pendapatan yang akan diterima manajer semakin tinggi.

Penelitian terkait pengaruh insentif ekuitas terhadap manajemen laba di Indonesia masih minim dilakukan. Penelitian yang telah dilakukan di Indonesia adalah Asyik (2006) dan Syariati et al. (2017). Maka dari itu, penelitian ini ingin mengeksplorasi kembali bagaimana pengaruh insentif ekuitas atau Employee Stock Option Plan (ESOP) terhadap Earning Management dengan periode penelitian berbeda yaitu 2015-2017 yang didasarkan pada peraturan terbaru OJK Nomor 38/POJK. 04/2014. Peraturan ini dibuat dengan tujuan supaya perusahaan lebih perhitungan dan tidak seenaknya menerbitkan saham untuk keperluan opsi saham (Wibawa, 2014). Oleh karena itu, dalam peraturan baru tersebut sudah terdapat pernyataan secara jelas bahwa jumlah opsi saham yang dapat diberikan kepada karyawan maksimal adalah $10 \%$ serta diimplementasikan dalam jangka waktu 5 tahun.

Berdasarkan uraian di atas, maka hipotesis yang dapat dirumuskan adalah Employee Stock Option Plan (ESOP) berpengaruh positif terhadap Earnings Management

\section{Metode}

Penelitian ini termasuk jenis penelitian kuantitatif eksplanatif yang bermaksud untuk menguji pengaruh ESOP terhadap Earnings Managements. Jenis data yang digunakan dalam penelitian ini adalah data sekunder yang diperoleh dari situs www.idx.co.id, dengan menggunakan teknik dokumentasi. Adapun populasi penelitian ini adalah seluruh perusahaan go public yang terdaftar di Bursa Efek Indonesia periode 2015-2017. Pemilihan jangka waktu dari 2015-2017 karena berlakunya peraturan baru terkait ESOP baru diterbitkan OJK pada tanggal 30 Desember 2014, yaitu peraturan OJK Nomor 38/POJK.04/2014. Sementara itu, sampel dalam penelitian ini dipilih melalui teknik purposive sampling dengan menetapkan kriteria, yaitu perusahaan go public yang memiliki program insentif ekuitas atau ESOP tahun 2015-2017. Berdasarkan kriteria yang telah ditetapkan diperoleh 10 perusahaan yang memenuhi kriteria dari 617 perusahaan go public yang terdaftar BEI. Oleh karena itu, selama 3 tahun penelitian total sampel secara keseluruhan adalah 30 laporan tahunan perusahaan. Selain itu, analisis data yang digunakan dalam penelitian ini adalah analisis deskriptif dan regresi linear data panel dengan programasi EViews 
Pengukuran variabel ESOP menggunakan proksi jumlah opsi saham yang dapat diberikan kepada karyawan dibagi jumlah saham beredar (Cheng et al., 2011; Ismail et al., 2017).

$$
\begin{array}{ll}
\text { ESOP } & =\frac{J S K}{J S B} \\
\text { ESOP } & : \text { Employee Stock Option Plan } \\
\text { JSK } & : \text { Jumlah opsi saham yang dapat diberikan kepada karyawan } \\
\text { JSB } & : \text { Jumlah saham beredar }
\end{array}
$$

Sementara itu, variabel earnings management diukur dengan menggunakan pendekatan discretionary accrual. Pendeteksian akrual diskresioner dilakukan dengan menggunakan Modified Jones Model. Berikut ini adalah langkah-langkah yang digunakan dalam pengukuran Modified Jones Model untuk memperoleh discretionary accrual:

\subsection{Total accrual}

TACCt $=$ Nlit - CFOit

TACCt $/$ TAt- $1=\beta 1(1 /$ TAt- 1$)+\beta 2(\Delta$ REVt $/$ TAt-1 $)+\beta 3($ PPEt $/$ TAt- 1$)+\varepsilon i t$

\subsection{Nilai nondiscretionary accrual (NDA)}

$\left.\mathrm{NDAt}=\beta_{1}\left(1 / \mathrm{TA}_{\mathrm{t}-1}\right)+\beta_{2}\left(\Delta \mathrm{REV}_{\mathrm{t}}-\Delta \mathrm{REC}_{\mathrm{t}}\right) / \mathrm{TA} \mathrm{t}-1\right)+\beta_{3}\left(\mathrm{PPE}_{\mathrm{t}} / \mathrm{TA} \mathrm{t}-1\right)$

\subsection{Earnings Management}

$\mathrm{EM}=\mathrm{TACC} \mathrm{t} / \mathrm{TAt}-1-\mathrm{NDAt}$

EM : Discretionary accrual perusahaan i pada periode $t$

NDAt : Non Discretionary accrual perusahaan i pada periode $t$

NIt : Net income perusahaan i pada periode $t$

TACCt : Total accrual perusahaan i pada periode $t$

CFOit : Aliran arus kas operasi perusahaan i pada periode $\mathrm{t}$

TAt-1 : Total aset perusahaan i pada periode sebelumnya

$\triangle$ REVt : Perubahan penjualan perusahaan i pada periode $t$

$\triangle$ RECT : Perubahan piutang usaha bersih perusahaan pada periode $t$

PPEit : Aset tetap perusahaan i pada periode $t$

cit : error

\section{Hasil dan Pembahasan}

\subsection{Analisis Deskriptif}

Tabel 1. Statistik Deskriptif

\begin{tabular}{lllll}
\hline & Minimum & Maximum & Mean & $\begin{array}{l}\text { Std. } \\
\text { Deviation }\end{array}$ \\
\hline ESOP & 0.000000 & 0.070000 & 0.009043 & 0.014058 \\
Earnings Management & -0.681293 & 0.096954 & -0.215944 & 0.242654 \\
\hline
\end{tabular}

Berdasarkan hasil statistik deskriptif pada Tabel 1 diketahui bahwa variabel ESOP memiliki nilai minimum sebesar 0,000000, maksimum ESOP sebesar 0,070000 dan rata-rata ESOP sebesar 0,009043 (0,9\%), yang berarti rata-rata pemberian ESOP kepada karyawan dari perusahaan sampel masih digolongkan rendah karena nilai tersebut masih jauh dibawah nilai 
maksimum pemberian ESOP yang ditetapkan dalam peraturan OJK No.38/POJK.04/2014 yaitu sebesar 10\%. Nilai standar deviasi dari ESOP sebesar 0,014058.

Sementara itu, untuk variabel manajemen laba nilai minimum discretionary accrual sebesar memiliki nilai minimum sebesar -0,681293, maksimum sebesar 0,096954 dan ratarata sebesar 0,215944 yang berarti rata-rata pola manajemen laba yang dilakukan oleh perusahaan sampel adalah menurunkan laba. Selanjutnya, untuk nilai standar deviasi discretionary accrual diperoleh sebesar 0,242654.

\subsection{Analisis Regresi Data Panel}

Langkah pertama untuk melakukan analisis data panel adalah menentukan mana model estimasi yang terbaik dalam penelitian ini. Model estimasi data panel dibagi menjadi tiga yaitu common effect mode, fixed effect model, dan random effect model. Ketika memilih model yang terbaik dapat ditentukan dengan menggunakan uji chow, uji Lagrange Multiplier, dan uji hausman. Berdasarkan uji yang telah dilakukan dapat dilihat hasilnya pada Tabel 3, yaitu sebagai berikut.

Tabel 2. Hasil Pemilihan Model Regresi Data Panel

\begin{tabular}{lll}
\hline Uji Model Regresi & Probability & Nilai \\
\hline Chow Test & Probability cross section chi-square & 0.0000 \\
LM Test & Probability cross section Breush-Pagan & 0.0000 \\
Hausman Test & Probability cross section random & 0.7949 \\
\hline Model Terpilih & Random Effect Model & \\
\hline
\end{tabular}

Diketahui dari Tabel 2 bahwa hasil uji chow menunjukkan nilai probability cross section chi-square sebesar $0,000<\alpha 0,05$, sehingga model estimasi yang terpilih adalah fixed effect model. Selanjutnya, dilanjutkan dengan uji LM, dari hasil uji yang dilakukan diketahui nilai probability cross section breush-pagan sebesar $0,0000<\alpha 0,05$, sehingga model estimasi yang terpilih adalah random effect model. Pengujian dilanjutkan dengan uji Hausman dan diperoleh nilai probability cross section random sebesar $0,7949>\alpha 0,05$, sehingga model estimasi yang lebih baik adalah random effect model. Berdasarkan 3 uji yang telah dilakukan dapat disimpulkan bahwa hanya 1 uji yang memilih fixed effect model dan 2 uji lainnya memilih random effect model sebagai model yang terpilih. Oleh karena itu, model estimasi yang terpilih dalam penelitian ini adalah random effect model.

Tahap pemilihan model estimasi regresi data panel telah dilakukan, maka tahap berikutnya melakukan uji asumsi klasik. Uji asumsi klasik yang dilakukan, yaitu sebagai berikut.

\subsubsection{Uji Normalitas}

Uji normalitas dalam penelitian ini menggunakan uji Jarque-Bera. Data dapat dikatakan terdistribusi dengan normal jika nilai probability Jarque-Bera > 0,05 (5\%). Pada Tabel 4.3 terlihat bahwa nilai probability Jarque-Bera sebesar 0,155450 >0,05, sehingga hipotesis H0 yang menjelaskan data berdistribusi dengan normal tidak dapat ditolak. 
Jurnal Ekonomi, Bisnis dan Pendidikan, 1(4), 2021, 313-322

Tabel 3. Uji Normalitas

\begin{tabular}{lll}
\hline Residual & Jarque-Bera & Probability \\
\hline Model 1 & 3.722856 & 0.155450 \\
\hline
\end{tabular}

\subsubsection{Uji Heteroskesdastisitas}

Pengujian heteroskedastisitas dilakukan dengan menggunakan uji white. Pengambilan keputusan uji white dengan melihat nilai probability dari Obs*R-Squred. Ketika nilai probability $>0,05$, maka dinyatakan terjadi homokesdastisitas. Model regresi yang baik adalah terbebas dari heteroskesdastisitas atau dengan kata lain terjadi homokesdastisitas.

Berdasarkan hasil uji heteroskedastisitas pada Tabel 4 menunjukkan bahwa model regresi sudah terbebas dari heteroskesdastisitas. Hal ini dapat dilihat dari nilai probability dari Obs*R-Squred sebesar 0,6251 >0,05. Lebih lanjut, hasil heteroskedastisitas dapat dilihat sebagai berikut.

\section{Tabel 4. Uji Heteroskedastisitas}

\begin{tabular}{llll} 
F-statistic & 0.436460 & Prob. F(2,27) & 0.6508 \\
Obs*R-squared & 0.939535 & Prob. Chi-Square(2) & 0.6251 \\
Scaled explained SS & 0.577793 & Prob. Chi-Square(2) & 0.7491 \\
\hline
\end{tabular}

\subsubsection{Uji Autokorelasi}

Uji autokorelasi dalam penelitian ini menggunakan uji Breush-Godfrey atau juga bisa disebut Lagrange Multiplier. Ketentuan terbebasnya model regresi dari autokorelasi dengan melihat nilai probability Obs*R-Squared. Jika nilai probability $>\alpha 0,05(5 \%)$ maka data tidak mengandung autokorelasi. Hasil uji autokorelasi yang telah dilakukan menunjukkan bahwa nilai hitung probability $0 b s^{*}$ R-Squared sebesar 0,1033 $>\alpha 0,05$, sehingga dapat dikatakan bahwa model regresi terbebas dari autokorelasi. Lebih lanjut, uji autokorelasi dapat dilihat pada Tabel 5 .

Tabel 5. Uji Autokorelasi

\begin{tabular}{llll} 
F-Statistic & 2.318431 & Prob. F(2,26) & 0.1184 \\
Obs*R-squared & 4.540474 & Prob. Chi-Square(2) & 0.1033 \\
\hline
\end{tabular}

Setelah data memenuhi uji asumsi klasik dan telah terpilih model yang paling cocok digunakan, yaitu random effect model, maka dapat dilakukan analisis regresi. Berdasarkan analisis yang dilakukan menunjukkan bahwa Employee Stock Option Plan tidak berpengaruh terhadap Earnings Management. Hal ini dibuktikan dari variabel ESOP yang memiliki nilai pvalue $0,0604>0,05$. Kemudian, nilai $R$ square yang dihasilkan dari penelitian ini sebesar 0,124 artinya variasi variabel Earnings Management dapat dijelaskan oleh variasi variabel ESOP sebesar 12,4\%. Lebih lanjut, untuk pengujian hipotesis dapat dilihat pada Tabel 6.

Tabel 6. Hasil Analisis Regresi Data Panel

\begin{tabular}{lllll}
\hline Variable & Coefficient & Std. Error & t-statistic & Probability \\
\hline (Constant) & -0.232788 & 0.083013 & -2.804243 & 0.0091 \\
ESOP & 1.862656 & 0.951746 & 1.957094 & 0.0604 \\
\hline
\end{tabular}


Berdasarkan analisis data yang telah dilakukan diperoleh kesimpulan bahwa Employee Stock Option Plan (ESOP) tidak berpengaruh terhadap Earnings Management. Terdapat beberapa faktor yang menjelaskan bahwa ESOP tidak berpengaruh terhadap manajemen laba. Faktor pertama, proporsi pemberian ESOP yang telah disetujui oleh pemegang saham dalam Rapat Umum Pemegang Saham (RUPS) rata-rata memiliki nilai yang rendah. Proporsi pemberian ESOP yang rendah membuat karyawan memiliki saham di perusahaan kecil, sehingga dikategorikan sebagai pemegang saham minoritas. Ketika karyawan menjadi pemegang saham minoritas maka mereka sulit mengendalikan kegiatan manajemen dan mengatur kebijakan operasi perusahaan sesuai dengan kehendaknya. Hal ini terjadi karena pengendalian perusahaan tetap menjadi wewenang dari pemegang saham sebelumnya yang memiliki kepemilikan mayoritas dan mereka tentunya juga mempunyai wewenang lebih untuk melakukan pengawasan atas jalannya perusahaan (Mukhtar \& Taqwa, 2016) sehingga tidak memberikan peluang bagi karyawan untuk bertindak sesuai keinginannya.

Faktor kedua, keberadaan ESOP sebagai salah satu bentuk kompensasi berupa insentif tidak mempengaruhi tindakan manajemen laba karena karyawan lebih fokus untuk mendapatkan jenis kompensasi lain seperti tunjangan hari raya yang diberikan dalam bentuk uang tunai. Hal ini didukung oleh hasil survei yang dilakukan oleh JobStreet.com pada 4.331 karyawan di Indonesia, dimana dari sejumlah responden tersebut 52,16\% karyawan memberikan pernyataan bahwa perusahaan memberikan kompensasi dalam bentuk tunjangan hari raya sebagai alat utama mengapresiasi karyawan (Wahyuni, 2016). Menurut Peraturan Menteri Ketenagakerjaan No. 6 Tahun 2016 kompensasi berupa tunjangan hari raya diberikan dalam bentuk uang dengan ketentuan menggunakan mata uang rupiah.

Negara Republik Indonesia. Di samping itu, perlu diketahui bahwa ESOP merupakan fenomena yang relatif baru di Indonesia (Firmansyah \& Sari, 2014). Adanya kondisi tersebut dapat mengakibatkan terbatasnya pengetahuan yang dimiliki oleh karyawan sehingga menjadi hambatan atas pelaksanaan ESOP (Susilawaty \& Dewi, 2017). Pada akhirnya, dengan terbatasnya pengetahuan yang dimiliki oleh karyawan dapat membuat mereka tidak menyadari akan keberadaan ESOP dan menjadikannya tidak berarti. Oleh karena itu, adanya kondisi-kondisi demikian dapat membuat karyawan tidak termotivasi untuk melakukan manajemen laba dengan adanya kompensasi berupa insentif ESOP tetapi lebih terfokus terhadap adanya kompensasi lainnya, seperti tunjangan hari raya berupa uang tunai.

Faktor ketiga, yang menyebabkan ESOP tidak berpengaruh terhadap manajemen laba karena perusahaan sampel telah menerapkan tata kelola perusahaan yang baik dilihat dari unsur komite audit. Semakin banyak jumlah komite audit perusahaan maka akan semakin menunjang keberagaman pengetahuan dan keahlian fungsi pengawasan yang dimiliki oleh komite audit terhadap pihak manajemen (Choi et al., 2004). Lebih lanjut, Laux \& Laux (2009) juga menyatakan bahwa peningkatan insentif ekuitas atau opsi saham tidak selalu mengarah pada tingkat manajemen laba yang lebih tinggi karena komite audit akan menyesuaikan upaya pengawasannya terhadap perilaku manajer. Oleh karena itu, meskipun karyawan atau manajer diberikan insentif dalam bentuk ekuitas atau opsi saham tetapi tingkat pengawasan yang dilakukan oleh komite audit meningkat, maka manajer tidak ada kesempatan untuk melakukan manajemen laba. 
Berdasarkan konteks penelitian ini diperoleh pengaruh yang positif antara ESOP dengan manajemen laba, dimana sesuai dengan hipotesis yang dibangun tetapi pengaruh tersebut tidak signifikan. Hal ini menjadi salah satu dasar pentingnya untuk dilakukan studi berikutnya. Sementara itu, jika dikaitkan dengan teori hasil penelitian ini tidak mendukung keberlakuan teori agensi (agency theory) yang menjelaskan bahwa konflik kepentingan antara agent dengan principal dapat terjadi karena masing-masing individu ingin memaksimalkan kepentingan dirinya sendiri. Untuk meminimalisir konflik tersebut, insentif berupa opsi saham tidak dapat digunakan sebagai alternatif penyelarasan tetapi alternatif penyelarasan yang lebih dapat digunakan adalah adanya komite audit. Komite audit dapat dijadikan sebagai alternatif penyelarasan karena tanggung jawab utamanya adalah mengawasi laporan keuangan supaya menjadi lebih berkualitas, sehingga dapat diandalkan (Alzoubi, 2019) serta memantau perilaku manajer (Fama \& Jensen, 1983).

Hasil penelitian ini sesuai dengan penelitian yang dilakukan oleh Maiyusti (2013) yang menemukan bahwa ESOP tidak memiliki pengaruh terhadap manajemen laba. Akan tetapi, hasil penelitian ini tidak berhasil membuktikan penelitian yang dilakukan oleh Alves (2012), Asyik (2006), Harris et al. (2019), Lee et al. (2011); Liu et al. (2014) McAnally et al. (2008), dan Syariati et al. (2017) yang menyimpulkan bahwa ESOP memiliki pengaruh yang positif terhadap manajemen laba.

\section{Simpulan}

Kesimpulan yang diperoleh dari penelitian ini adalah Employee Stock Option Plan (ESOP) tidak berpengaruh terhadap Earnings Management. Hal tersebut dapat terjadi disebabkan oleh beberapa faktor diantaranya rata-rata pemberian ESOP memiliki nilai yang rendah, karyawan lebih terfokus terhadap kompensasi lainnya seperti tunjangan hari raya berupa uang tunai yang dianggap lebih familiar, dan perusahaan sampel telah memiliki tata kelola perusahaan yang baik dilihat dari unsur komite audit.

Adapun keterbatasan dalam penelitian ini adalah (a) Periode yang digunakan dalam penelitian ini tergolong cukup pendek yaitu 3 tahun (2015-2017), (b) Tidak dapat menjelaskan pengaruh ESOP terhadap manajemen laba pada masing-masing sektor, (c) Terkhusus pada sektor manufaktur kegiatan manajemen laba tidak hanya dilakukan pada aktivitas akrual tetapi juga riil. Akan tetapi, penelitian ini hanya terfokus pada pengukuran manajemen laba dari sisi akrual. Maka dari itu, kemungkinan perilaku manajemen laba masih belum mencerminkan keadaan secara keseluruhan.

Berdasarkan keterbatasan penelitian maka saran yang dapat diberikan kepada investor yaitu dalam menjaga kepentingan di perusahaan sebaiknya investor tidak hanya mempertimbangkan keberadaan ESOP tetapi juga mengamati tata kelola perusahaan secara mendalam. Kemudian, bagi Manajer hendaknya tidak melakukan tindakan manajemen laba sebab akan merugikan banyak pihak dan mengakibatkan berkurangnya kredibilitas perusahaan. Selanjutnya, bagi pengembangan penelitian selanjutnya saran yang dapat diberikan, yaitu (a) Menambah periode penelitian minimal 5 tahun penelitian karena periode pelaksanaan ESOP yang telah ditetapkan di peraturan OJK adalah lima tahun, (b) Melaksanakan penelitian dengan mengelompokkan jenis perusahaan sesuai dengan sektornya (c) Ketika melibatkan penelitian dari sektor manufaktur disarankan untuk menambahkan pengukuran manajemen laba dari sudut pandang yang berbeda yaitu menggunakan pengukuran berdasarkan aktivitas riil (d) Saat melakukan penelitian yang melibatkan sektor 
perbankan terdapat pengukuran manajemen laba yang lebih spesifik, yaitu menggunakan proksi pengukuran manajemen laba discretionary loan loss provision.

\section{Daftar Rujukan}

Alves, S. (2012). Executive stock options and earnings management in the Portuguese listed companies. Revista de Contabilidad, 15(2), 211-235.

Alzoubi, E. S. S. (2019). Audit committee, internal audit function and earnings management: evidence from Jordan. Meditari Accountancy Research.

Asyik, N. F. (2006). Dampak Pernyataan Nilai Wajar Opsi Pada Pengaruh Magnituda Kompensasi Program Opsi Saham Karyawan Terhadap Pengelolaan Laba. Simposium Nasional Akuntansi 9 Padang.

Bapepam. (2002). Emiten Atau Perusahaan Publik. Badan Pengawas Pasar Modal, 1-103.

Chen, Y. C., Lee, C. H., \& Chou, P. I. (2015). Stock-Based Compensation and Earnings Management Behaviors. Review of Pacific Basin Financial Markets and Policies, 18(2), 1-33. https://doi.org/10.1142/S0219091515500083

Cheng, Q., Warfield, T., \& Ye, M. (2011). Equity incentives and earnings management: Evidence from the Banking Industry. Journal of Accounting, Auditing and Finance, 26(2), 317-349. https://doi.org/10.1177/0148558X11401219

Choi, J. H., Jeon, K. A., \& Park, J. Il. (2004). The Role of Audit Committees in Decreasing Earnings Management: Korean Evidence. International Journal of Accounting, Auditing and Performance Evaluation, 1(1), 3760. https://doi.org/10.1504/IJAAPE.2004.004142

Essid, W. (2012). Executive Stock Options and Earnings Management: Is There an Option Level Dependence? Corporate Governance: The international journal of business in society 12(1), 54-70. https://doi.org/10.1108/14720701211191337

Fama, E. F., \& Jensen, M. C. (1983). Separation of Ownership and Control. The Journal of Law \& Economics, 26(2), 301-325.

Firmansyah, S. R. (2014). Pengaruh Kebijakan Employee Stock Ownership Program (ESOP) Pada Kinerja Keuangan Perusahaan Yang Terdaftar Di Bursa Efek Indonesia (Doctoral dissertation, STIE PERBANAS).

Goldman, E., \& Slezak, S. L. (2006). An Equilibrium Model of Incentive Contracts in the Presence of Information Manipulation. Journal of Financial Economics, 80, 603-626. https://doi.org/10.1016/j.jfineco.2005.05.007

Harris, O., Karl, J. B., \& Lawrence, E. (2019). CEO Compensation and Earnings Management: Does Gender Really Matters? Journal of Business Research, 98, 1-14. https://doi.org/10.1016/j.jbusres.2019.01.013

Hartomo, G. (2019). Kronologi Kasus Laporan Keuangan Garuda Indonesia hingga Kena Sanksi. (online), https://economy.okezone.com/read/2019/06/28/320/2072245/kronologi-kasus-laporankeuangan-garuda-indonesia-hingga-kena-sanksi, diakses 25 November 2019.

Iskan, D. (2019). Laba Garuda. Diambil 25 November 2019, dari https://www.disway.id/r/528/laba-garuda

Ismail, Z., Dockery, E., \& Ahmad, A. S. (2017). Does stock options plan really matter on the Malaysian firm performance? Journal of Contemporary Issues and Thought, 7, 104-118.

Jensen, C., \& Meckling, H. (1976). Theory of the Firm: Managerial Behavior, Agency Costs and Ownership Structure. Journal of Financial Economics, 3, 305-360.

Keuangan, O. J. Peraturan No. 55/POJK. 04/2014 tentang Pembentukan dan Pedoman Pelaksanaan Kerja Komite Audit. (Online). (www.ojk.co.id), diakses 19 Maret 2020

Keuangan, O. J. (2015). Peraturan Otoritas Jasa Keuangan Nomor 36/POJK. 05/2015 Tentang Tata Kelola Perusahaan Yang Baik Bagi Perusahaan Modal Ventura. (Online). (www.ojk.co.id), diakses 25 November 2019.

Laux, C., \& Laux, V. (2009). Board Committees, CEO Compensation, and Earnings Management. The Accounting Review, 84(3), 869-891. https://doi.org/10.1007/s11142-014-9291-x

Lee, K. T., Lee, S. C., \& Choi, S. (2011). Relationship Between Executive Stock Option Exercises and Earnings Management. Asia-Pacific Journal of Financial Studies, 40, 856-888. https://doi.org/10.1111/j.20416156.2011.01060.x 
Liu, L., Liu, H., \& Yin, J. (2014). Stock Option Schedules and Managerial Opportunism. Journal of Business Finance and Accounting, 41(5-6), 652-684. https://doi.org/10.1111/jbfa.12075

Maiyusti, A. (2013). Pengaruh Asimetri Informasi, Kepemilikan Manajerial dan Employee Stock Ownership Program Terhadap Praktik Manajemen Laba (Perusahaan Manufaktur Yang Terdaftar di Bursa Efek Indonesia Tahun 2007-2012). Jurnal Akuntansi, 2(1).

McAnally, M. L., Srivastava, A., \& Weaver, C. D. (2008). Executive Stock Options, Missed Earnings Targets, and Earnings Management. Accounting Review, 83(1), 185-216. https://doi.org/10.2308/accr.2008.83.1.185

Mukhtar, N. (2016). Pengaruh Earning Power, Kecakapan Manajerial dan Employee Stock Ownership Program terhadap Manajemen Laba Riil (Studi Empiris Perusahaan Manufaktur yang Terdaftar di Bursa Efek Indonesia Tahun 2010-2014). Jurnal Akuntansi, 4(1).

Nomor, P. M. K. (6). Tahun 2016 tentang Tunjangan Hari Raya Keagamaan bagi Pekerja. Buruh di Perusahaan. (Online). (www.jdih.kemnaker.go.id), diakses 13 Agustus 2020

Oyer, P., \& Schaefer, S. (2005). Why Do Some Firms Give Stock Options to All Employees?: An Empirical Examination of Alternative Theories. Journal of Financial Economics, 76, 99-133. https://doi.org/10.1016/j.jfineco.2004.03.004

Richardson, V. J. (1998). Information Asymmetry and Earnings Management: Some Evidence. Review of Quantitative Finance and Accounting, 15(4), 325-347. https://doi.org/10.1023/A:1012098407706

Shabani, V., Mir Aghaei, S. M., \& Shabani, V. (2014). Investigating the relationship between earnings and stock prices in companies accepted in the stock exchange: A case study in Iran (2000-2010). European Online Journal of Natural and Social Sciences, 2 (3 (s)), pp-3102.

Shan, W., \& An, R. (2018). Motives of stock option incentive design, ownership, and inefficient investment. Sustainability, 10(10), 3484. https://doi.org/10.3390/su10103484

Susilawaty, L., \& Dewi, D. (2017). Analisis Dampak Penerapan ESOP (Employee Stock Ownership Program) Terhadap Kinerja Perusahaan Yang Terdaftar Di Bursa Efek Indonesia. Business Management Journal, 13(2).

Syariati, N. E., Subroto, B., \& Andayani, W. (2017). The Role of Employee Stock Option Plan to Reduce Earnings Management Actions. Jurnal Keuangan dan Perbankan, 21(3), 196443. https://doi.org/10.26905/jkdp.v21i3.1281

Trisnawati, R., Wiyadi, \& Nugraheni, D. (2015). The Analysis of Information Asymmetry, Profitability, and Deferred Tax Expense on Integrated Earning Management. South East Asia Journal of Contemporary Business, Economics and Law, 7(1), 17-24.

Wahyuni, N. D. (2016). Survei: 77\% Karyawan Tak Puas dengan Tunjangan yang Diterima. (online), https://www.liputan6.com/bisnis/read/2418890/survei-77-karyawan-tak-puas-dengan-tunjanganyang-diterima, diakses 2 Agustus 2020.

Wibawa, A. A. (2014). OJK Akan Mengatur MSOP dan ESOP. (online), https://investasi.kontan.co.id/news/ojkakan-mengatur-msop-dan-esop, diakses 26 November 2019.

Wu, M. C., Huang, Y. T., \& Chen, Y. J. (2012). Earnings Manipulation, Corporate Governance and Executive Stock Option Grants: Evidence from Taiwan. Asia-Pacific Journal of Financial Studies, 41, 241-257. https://doi.org/10.1111/j.2041-6156.2012.01072.x 